\title{
The present and future of Mediterranean floristics
}

\author{
edited by Benito Valdés
}

\begin{abstract}
Valdés, B. (ed): The present and future of Mediterranean floristics. — Fl. Medit. 23: 173-214. 2013. - ISSN: 1120-4052 printed, 2240-4538 online.

The texts of four of the six communications presented in the Symposium The present and future of Mediterranean floristics, as a part of the scientific programme of the XIV OPTIMA Meeting which took place in Palermo in September 2013, are included
\end{abstract}

The symposium on The present and future of Mediterranean floristics took place in Palermo on Wednesday, 11 September, as a part of the scientific programme of the XIV OPTIMA Meeting (Palermo, September 9-15, 2013). It included the following communications: Introduction, with special reference to the Flora iberica project, by B. Valdes (Seville); Horizons des recherches floristiques au Maroc, by M. Fennane (Rabat); Etat des lieux et perspectives de recherches sur la flore méditerranéenne d'Algerie et Tunisie, by E. Véla (Montpellier); The present and future of the flora of Greece and its conservation assesment, by G. Kamari (Patras); Mediterranean flora and its conservation in Turkey, with special reference to Monocot geophytes, by N. Özhatay (Istanbul); Josif Pančić and the New Flora of Serbia, by O. Vasić (Belgrade)The text of the following four communications are included in this volume of Flora Mediterranea as indexed below:

\section{INDEX}

B. Valdés: Introduction, with special reference to the Flora iberica project 175

G. Kamari: The present and future of the flora of Greece and its conservation assesment . 183

N. Özhatay, M. Koçyiğit, S. Yüzbaşığlu \& B. Gürdal: Mediterranean flora and its conservation in Turkey, with special reference to Monocot geophytes

O. Vasić: Josič Pančić and the New Flora of Serbia 209

Address of the editor:

Departamento de Biología Vegetal y Ecología, Facultad de Biología, Universidad de Sevilla, 41012 Sevilla, Spain. E-mail: bvaldes@us.es 
